\title{
Text and Context: Special Collections and Scholarship
}

\section{Anne Lundin}

Changes in scholarly disciplines create new relationships for special collections. The increasing openness of scholarly disciplines in the humanities and social sciences inspires a search for manuscripts and the study of text in a broad context. Literary theories of New Criticism and New Historicism place new prominence on manuscripts and historical works, long the provenance of special collections. This fuller historical perspective elevates populist concerns and popular culture materials. Children's literature is an example of a field being explored by literary scholars and social historians in new understandings of text and context. The changing patterns of academic scholarship make the special collection "a museum without walls."

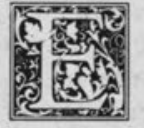

lizabeth Eisenstein's landmark study, The Printing Press as an Agent of Change, illuminates the far-reaching implications of the printing inventions of the fifteenth century. Some of these change-producing effects were the widening of scholarship, a collaborative approach to the collection of data, an ability to improve and correct texts once published, and an interchange between disciplines. She suggests that these cultural transformations are an ongoing process, "still responsible for our museum-without-walls".

Our contemporary world of scholarship reveals this continuing evolution. A quiet, yet profound, change has been taking place in the humanities and the social sciences during the last decade. The increasing openness of scholarly disciplines has created a new relationship for special collections, where text and context interact in the spirit of E.N. Forster's celebrated plea, "Only Connect!",2

The connection between libraries and scholarship has traditionally created a synergy. Elmer Johnson and Michael Harris in their history of libraries attribute the genesis of modern librarianship to the invention of printing, in the sense that expanding library collections made possible by the printing press stimulated the emergence of a profession charged with its care. ${ }^{3}$ The beginning of humanism coincided with the revival of libraries as depositories of books to be read and not just to be stored. The renewed appreciation of classical literature and the interest in an enhanced knowledge of what ancient writers had actually written impelled the search for manuscripts and their placement in libraries where scholars could find them and read them. ${ }^{4}$.

A similar renaissance in the late twentieth century has inspired the scholarly search for manuscripts and the study of text in a broad context. The tradition of formal, structural, text-centered literary studies, known as the New Criticism, is now competing with an emphasis on historical bibliography and social history, known as the New Historicism. This tugof-war among literary scholars places new prominence on manuscripts and historical works, long the provenance of special collections.

For years the text was supreme in literary criticism. The New Critics espoused

Anne Lundin is Assistant Curator, de Grummond Collection, University of Southern Mississippi, Hattiesburg, Mississippi 39406-5148. 
the isolation of the text as the sole determinant of meaning; biography and sociology were beyond the domain. A challenge to this self-enclosed construct is contained in the criticism of the New Historicists, whose interpretation is historically grounded in the referential aspects of literary works. Jerome McGann, a leading historicist, defines the new emphasis: "Criticism moves in constant pursuit of the text's lost and unrealized points of reference, all the verbal and eventual matters of fact which constitute the work's symbolic networks. ${ }^{55}$ This approach considers the entire socio-history of a literary work, from its origins through its subsequent textual adventures.

This fuller historical perspective includes an interest beyond the celebrities of the past to the daily concerns of everyday people. To that end, cultural, political, economic, ideological, and social issues are studied for the way they shape a text. The French philosopher Michael Foucault, a guiding force, argues that everything, even social institutions, can be read as "texts," and that cultural values and concepts are products of a given time, not absolutes. ${ }^{6}$ Instead of viewing culture as a seamless whole, embodying a hierarchy of values, the historicists see it as decentralized and divided.

\section{"This focus on cultural diversity is reflected in a boom of interest in pop- ulism."}

This focus on cultural diversity is reflected in a boom of interest in populism. English departments heatedly debate the inclusion of popular literature into the sacred canon of traditional texts. Burgeoning social concerns lead scholars to question traditional works for their ideology. A decade ago, in his study of academic scholarship, Charles Osborn viewed this sociological approach as the most significant trend for the future. ${ }^{7}$ Scholars examine texts for a mirror of their social world, which often leads to monumental revisions in interpretation.
The growth of studies in popular culture is evidence of populist concerns. In less than two decades, the Popular Culture Association has grown from a special collection to an international, interdisciplinary organization. Ray and Pat Browne, the founders, were convinced that the vast body of materials for mass consumption-in print, film, television, comics, advertising, graphics, and folk culture-was worthy of scholarly pursuit. In a rare phenomenon, a special collection inspired the growth of a body of scholarship, a press, and a professional association, as its mission not only reflected but created intellectual trends.

These pursuits are cross-fertilizations of disciplines, reflective of new branches of learning. Disciplinary lines have become blurred through the increased presence of technology in all aspects of life, particularly in quantification and data analysis in methods of research. History and literary criticism now borrow heavily from psychology, sociology, and anthropology. Linguistics has divided into psycholinguistics and sociolinguistics. In history, new areas of urban history, women's history, economic history, and black history have come to the fore. Paul Boyer, professor of history at the University of Wisconsin, is quoted in the Chronicle of Higher Education as saying, "The best history is being done from a more integrated perspective. Historians are broadening their definition of what you have to look at to do history within various specialties. ${ }^{\prime \prime 8}$

This new breadth reveals an evolving understanding of what constitutes a discipline. In field after field, scholars speak of boundaries extending or breaking down and of their looking beyond themselves and joining the general intellectual conversation. 9 This transcendence of discipline limits creates a new legitimacy for the special collection as a literary witness to the universe of knowledge.

Scholars are turning to special collections for their unique manuscript holdings and rare book materials, which constitute text and context. Special collections have traditionally housed the fragile, scarce item in whatever format: old photographs and film, ephemera, maps, personal 
memorabilia, commercial and legal documents, as well as original manuscripts and old books. These are the very sources now zealously sought by scholars. Literary researchers seek out original manuscript versions of a text instead of printed books, often replete with errors and omissions. Historians investigate archives for correspondence and records of political and social activity. Older publications and periodicals of the eighteenth and nineteenth century become vital primary sources.

This attention to primary source material creates new prominence for the special collection. Michael Keresztesi has eloquently described the bibliographic culture as "a condition in which genuine respect for the library prevails; its resources are creatively utilized for all educational, research, cultural, and recreational activities; and librarians are accepted as equal partners in a joint educational enterprise. ${ }^{110}$ While Keresztesi's theories have been applied largely to the bibliographic instruction movement, there are parallels in the intimacy of curator and scholar that originates from imaginative collaborative actions: the acquisition of nontraditional sources, segments saved of a larger cultural, literary, and intellectual heritage; and the instruction in their use. Bibliographic instruction is as essential to special collections as it is to general reference in leading the scholar to the unknown.

Curators become educators as they lead scholars through what Keresztesi calls the "topography of knowledge," to the exploration of manuscripts and their textural mystery. Jerome McGann and other scholars appreciate their dependence on such a guide in their detailed research: "Critics are now aware of the necessity of serious archival work. You have to get into original material. You have to trace through the history of texts, and you have to trace through the history of reception of texts. You can't do that by sitting in your office and producing a clever interpretation. ${ }^{11}$ William Joyce connects the growing authority of the research collection and the library profession. In a symposium at the Center for the Book at the Library of Congress, Joyce, a special collections curator at Princeton University, traces the col- lection of manuscripts by librarians who recognized their value despite scholarly neglect. "Now testimony suggests," says Joyce, "that those librarians working with special collections have inverted the traditional procedure and are training scholars in the use of primary sources." 12 This training involves considerable intellectual content, gathered in the selection, processing, cataloging, and exhibiting of these original materials.

\section{"Just as the text contains a textual- ized frame of reference, so also does the background collection, the con- text, become primary in the text's comprehension."}

The training is also of the eye, of the ability to see context as text. The librarian knows that no manuscript is autonomous and self-contained, that, in the words of Gerald Graff, "no text is an island, that every work of literature is a rejoinder in a conversation or dialogue that it presupposes but may or may not mention explicitly. ${ }^{13}$ This larger conversation to which works of literature refer is the cultural text. Just as the text contains a textualized frame of reference, so also does the background collection-the context-become primary in the text's comprehension.

This metaphorical leap is the philosophical rationale to a special collection. $\mathrm{Pa}$ trons come to a special library for a physical object-a book, a periodical, a manuscript-and are introduced to the contextual framework of that object. Text becomes context in the discovery of differences being related, of a larger world extrinsic and intrinsic in meaning.

These discoveries, small epiphanies, occur often in special collections like the de Grummond Children's Literature Research Collection. Researchers come for a particular source or obscure title and, in the process of interaction between patron and librarian, a mirror illuminates social values, family life, and cultural concepts. Children's literature is particularly rich in 
its textural connection. This primary material, in which the skills, values, and preoccupations of society are recorded and transmitted, whether deliberately or unconsciously, is a largely untapped source of information about morals, family, and social relationships, and the details of everyday life. ${ }^{14}$

The humanities and social sciences are discovering children's books as comparative literature. Peter Neumeyer places children's books across a wide spectrum of cultures, in many historical eras, and in relation to other fields such as psychology, education, librarianship, and fine arts. To Neumeyer, "Children's literature exists in diverse cultures, reflects them, travels from one to another, as may strikingly be seen in the folk-fairy tales children have appropriated as their own. ${ }^{\prime 15}$

The transformations of a simple children's book into studies in textual history, in biography, in socio-history, in archetype or myth are the stuff of dreams, the metaphors of special collections. In the changing patterns of academic scholarship, the special collection becomes the museum-without-walls, a world of text that becomes our inheritance.

\section{REFERENCES}

1. Elizabeth Eisenstein, The Printing Press as an Agent of Change (New York: Cambridge, 1979), p.704.

2. P.L. Travers, "'Only Connect,"' in Sheila Egoff, Only Connect (New York: Oxford, 1980), p.184.

3. Elmer D. Johnson and Michael H. Harris, History of Libraries in the Western World (Metuchen, N.J.: Scarecrow, 1976), p.136.

4. Edward Shils, Tradition (Chicago, Ill.: Univ. of Chicago, 1981), p.146.

5. Jerome McGann, Historical Studies and Literary Criticism (Madison: Univ. of Wisc., 1985), p.15.

6. Angus Paul, "Literature's Romantic Era: Historicists Re-Interpret It and Generate Controversy Among Their Colleagues," Chronicle of Higher Education 34:A7 (13 April 1988).

7. Charles Osburn, Academic Research and Library Resources: Changing Patterns in America (Westport, Conn.: Greenwood, 1979), p.84.

8. Ellen K. Coughlin, "Humanities and Social Sciences: The Sound of Barriers Falling," Chronicle of Higher Education 34:A6 (2 Sept. 1987).

9. Ibid., p.A6.

10. Michael Keresztesi, "Bibliographic Instruction in the 1980s and Beyond," in Carolyn Kirkendall, Directions for the Decade: Library Instruction in the 1980s (Ann Arbor, Mich.: Pierian, 1981), p.41.

11. Paul, "Literature's Romantic Era," p.A5.

12. Nancy E. Gwinn, "Report from a Conference at the Library on Libraries and Scholarly Communication in the United States," Library of Congress Information Bulletin 47:164 (18 April, 1988).

13. Gerald Graff, Professing Literature: An Institutional History (Chicago, Ill.: Univ. of Chicago, 1987), p.10.

14. See James Fraser, Society and Children's Literature (American Library Assn., 1978); R. Gordon Kelly, Mother Was a Lady (Greenwood, 1974); Anne Lundin, "Historical Children's Literature Collections: Sources for Research," Social Education 51:524 (Nov./Dec. 1987).

15. Peter Neumeyer, "Children's Literature in the English Department," Children's Literature Association Quarterly 12:147 (Fall 1987). 